\title{
NA REVOLUÇÃO FRANCESA, OS PRINCÍPIOS DEMOCRÁTICOS DA ESCOLA PÚBLICA, LAICA E GRATUITA: O RELATÓRIO DE CONDORCET
}

\author{
Carlota Boto*
}

\begin{abstract}
Mas parece-nos que atingiríamos o duplo objetivo de assegurar à pátria todos os talentos que podem servi-la e de não privar nenhum indivíduo da vantagem de desenvolver os que recebeu, se as crianças que revelarem maior capacidade, num grau de instrução, fossem chamadas a freqüentar o grau superior e mantidas à custa do tesouro nacional, sob o nome de alunos da pátria.
\end{abstract}

(Condorcet, 1943, p. 54)

RE SU M 0: 0 presente artigo analisa e procura fomentar o debate acerca de proposta expressa em 1792, pela Comissão de Educação da Assembléia Legislativa Francesa - e apresentada por Condorcet. Sua matéria reside em um plano de organização da instrução pública arquitetado pelos revolucionários com 0 propósito de formar 0 povo. Pretendiam os revolucionários criar o homem novo, para dar conta de levar adiante a Revolução que se iniciara. Tratava-se - como diziam - de engendrar uma pátria regenerada, capaz de efetivar os princípios de uma sociedade verdadeiramente democrática. Sendo assim, supunha-se ser a escolarização um dos veículos prioritários na construção da nacionalidade. A Assembléia Legislativa traçou, portanto, um plano educacional expondo os níveis e métodos de ensino, a organização do ensino, os critérios de seleção dos profissionais da educação, os procedimentos de políticas públicas e de avaliação da rede escolar. Trata-se de um prospecto de modelo para a composição de uma escola nacional, tal como esta se constituiria a partir do século XIX. Trata-se, sobretudo, de uma referência pedagógica da qual so-

Doutora em História Social pela FFLCH-USP e professora da área de Filosofia da Educação da FEUSP. E-mail: carlotaboto@uol.com.br

E duc. Soc., Campinas, vol. 24, n. 84, p. 735-762, setembro 2003

Disponível em <http:/ / www.cedes.unicamp.br> 
mos todos herdeiros; especialmente quando, no coletivo, expressamos a defesa de uma forma de escola ainda pública, universal, única para todos, gratuita e tolerante. D e alguma maneira, a compreensão desse modelo de escola, em suas raízes histórico-sociais, oferece ainda uma matriz analítica para pensarmos na possibilidade de defesa também da universidade pública, como coroamento maior da prometida igualdade de oportunidades de acesso.

Palavras-chave: Iluminismo. Educação. Instrução pública. Ensino. Condorcet. Revolução Francesa.

\title{
THE DEMOCRATIC PRINCIPLES OF PUBLIC, LAY AND FREE EDUCATION DURING THE FRENCH REVOLUTION: THE CONDORCET REPORT
}

\begin{abstract}
A BST RA CT: This paper analyzes the debate on the proposals Condorcet presented, in 1792, on behalf of the Education Commission of the French Legislative Assembly. It deals with organizing the public education conceived by the revolutionaries to form the people and create a new man who could carry out the Revolution they had begun. As they said, the issue was to regenerate the mother country and ensure that the principles of a truly democratic society became effective. Therefore, education was supposed to be one of the priorities for nationality building. The Legislative Assembly thus drew up an education plan establishing the levels and teaching methods, the education organization, the selection criteria for the education professionals, and the public policy procedures to assess the school network. It was a prospective model for the setting up of the national education, which would be implemented from the $\mathrm{XIX}^{\text {th }}$ century on. Above all, this pedagogical reference constitutes our heritage, especially when we collectively defend a form of school that is still public, universal, standard for everybody, tolerant and free. In a sense, understanding this school model in its social and historical roots also offers an analytical matrix to think the possibility of also defending public university as the major crowning achievement of the promised equality of opportunities.
\end{abstract}

Key words: Enlightenment. Social history. Public education. Condorcet. French Revolution.

\section{O que é a ilustração? Entre dilemas e disputas}

E

m sua "Resposta à pergunta: que é o Iluminismo?", em 1784, Kant definia: "O Iluminismo é a saída do homem da sua menoridade de que ele próprio é culpado. A menoridade é a incapacidade de se servir do entendimento sem a orientação de outrem. Tal menoridade é por culpa própria se a sua causa não reside na falta 
de entendimento, mas na falta de decisão e de coragem em se servir de si mesmo sem a orientação de outrem. Sapere aude! Tem a coragem de te servires do teu próprio entendimento! Eis a palavra de ordem do Iluminismo" (K ant, 1989, p. 11).

Para o Iluminismo - e a reflexão de Kant explicita isso - menoridade intelectual significa a incapacidade humana de servir-se da própria razão e 0 conseqüente recurso a opiniões alheias para a formação dos próprios juízos. Nesse estado, o homem - cujas especificidades no mundo da natureza se traduziam exatamente, por um lado, pela faculdade de julgar e, por outro, pela autonomia da sua vontade - deixaria de se valer dos recursos intrínsecos à sua condição humana. D estituído do desenvolvimento potencialmente inscrito em sua natureza, o indivíduo privar-se-ia - por paradoxal que isso possa parecer - do próprio direito natural da liberdade. Do ponto de vista do Iluminismo - e mais precisamente dessa exposição de Kant sobre o tema - , a liberdade exige a autonomia plena da razão perante lógicas externas, heterônomas a ela. Q uando não se serve de seu próprio entendimento, 0 espírito não obtém a maioridade da razão e a liberdade de julgamento. Em estado de menoridade, o indivíduo (e, quando, no coletivo, o povo), impedido de pensar por si próprio e ouvir as recomendações de sua consciência individual esclarecida, pede tutor e controle alheio; prende-se àquele que ilumina suas opiniões; cria oráculos e, com eles, amarras para seu pensamento. ${ }^{1} \mathrm{~K}$ ant, naquele opúsculo, expressava sua firme convicção de que nem mesmo a ocorrência de uma possível revolução - contra o despotismo, contra os privilégios - seria suficiente para engendrar, nas subjetividades, nos corações e nas mentes, formas autônomas de raciocinar sobre o homem e sobre 0 mundo: normas pautadas exclusivamente pela vontade livre e soberana e pela razão independente e indagadora. Não era o que ocorria em seu tempo:

Semear preconceitos é muito pernicioso, porque acabam por se vingar dos que pessoalmente, ou os seus predecessores, foram os seus autores. Por conseguinte, um público só muito lentamente pode chegar à ilustração. Por meio de uma revolução poderá talvez levar-se a cabo a queda do despotismo pessoal e da opressão gananciosa ou dominadora, mas nunca uma verdadeira reforma do modo de pensar. Novos preconceitos, justamente como os antigos, servirão de rédeas à grande massa destituída de pensamento. Mas, para esta ilustração, nada mais se exige do que a liberdade; e, claro está, a mais inofensiva entre tudo o que se pode chamar liberdade, a saber, a de fazer um uso público da sua razão em todos os elementos. Mas agora ouço gritar de 
todos os lados: não raciocines! D iz o oficial: não raciocines, mas faz exercícios! D iz o funcionário de Finanças: não raciocines, paga! E o Clérigo: não raciocines, acredita! (Apenas um único senhor no mundo diz: raciocinai tanto quanto quiserdes e sobre o que quiserdes, mas obedecei!) Por toda a parte se depara com a restrição da liberdade. Mas qual é a restrição que se opõe ao Iluminismo? Q ual a restrição que não o impede, mas antes o fomenta? Respondo: 0 uso público da própria razão deve sempre ser livre e só ele pode levar a cabo a ilustração. (Kant, 1989, p. 13)

Por uso público da razão, Kant compreendia aquele que o erudito faz perante o ambiente letrado com o qual dialoga - ou a quem, no mínimo, toma por interlocutor: uso, portanto, intencional, manifesto, reconhecido, notório e compartilhado. O sujeito das ciências e das letras, o estudioso - aquele a quem Kant nomeia erudito - teria por vocação e por missão partilhar com seus leitores, com seus ouvintes, com seus estudantes - enfim, com seu público - suas indagações e seus questionamentos, suas hipóteses e teses (sempre provisórias e passíveis de submeter-se à crítica), suas dúvidas e incertezas perante 0 território do saber que ele próprio investiga, trazendo para o conhecimento, ao mesmo tempo, admiração, espanto e perplexidade. Sem isso, não poderia existir honestidade intelectual. 0 relato moderno que organiza e classifica, a seu modo, a realidade deveria trazer, como contrapartida, a explicitação da falibilidade indelevelmente inscrita no coração de seu próprio projeto de mundo.

D o ponto de vista kantiano, o erudito é o indivíduo que coloca a realidade, metodologicamente, sob o crivo crítico da dúvida - sujeitando-se sempre a novas indagações sobre seus escritos, sobre os critérios que teriam pautado sua investigação, sobre as fontes e os recursos de que se valeu na construção do saber produzido. Com hipóteses e metodologia compartilhadas e postas a público, o conhecimento científico ganharia credibilidade - diferenciando-se do mito, da opinião, da religião, das crendices populares e de quaisquer orientações dogmáticas. ${ }^{2}$ Tratava-se de estruturar uma gramática lógica do saber erudito, a qual necessitava, preliminarmente, ser comunicada aos pares, para, a seguir, ser traduzida para a linguagem comum. Em outras palavras, pode-se dizer que 0 anseio por ampliar e irradiar 0 conhecimento produzido coincidia com a própria percepção de uma época que se desejava iluminista e que não supunha como razoável a recusa do esclarecimento: "Sem dúvida, um homem, para a sua pessoa, e mesmo então só por algum tempo, pode, no que lhe incumbe saber, adiar a instrução; mas renunciar a ela, quer seja para si, quer 
ainda mais para a descendência, significa lesar e calcar aos pés o sagrado direito de humanidade" (Kant, 1989, p. 16). O Iluminismo tinha, assim, a crença de que o ser humano traria com ele a "vocação para 0 pensamento livre" (idem, ibid., p. 19); e este, por sua vez, requeria 0 preparo da desenvolução racional para aprimorar-se e, para além da potência, atualizar-se em ato.

Leon Cahen destaca em seu trabalho que, no movimento ilustrado do século XVIII, ocorreu uma proeminência no debate - anteriormente de menor intensidade - a propósito da ação do Estado na matéria educacional. Os iluministas compreendiam que a instrução conduzia não apenas a um acréscimo de conhecimento, mas também à melhoria do indivíduo que se instrui. Diderot, por exemplo - segundo relata Cahen - compreendia que instruir uma nação equivale a civilizá-la (Diderot, apud Cahen, 1970, p. 326). ${ }^{3}$

Como sublinha Roberto Romano, o pensamento de Diderot operava com metáforas mecânicas de compreensão do social. A operação da máquina, na atividade prática de seu funcionamento, é, por definição, maior que a inteligibilidade de suas partes, tomadas cada uma separadamente, em sua órbita interna (Romano, 2003, p. 62). Por analogia, poder-se-ia dizer que a instrução era - no mesmo Século da Luzes - um conceito operatório do concerto da civilização que se julgava construir. Era parte de uma engrenagem, cujo significado ultrapassava a lógica do mecanismo escolar. Roberto Romano destaca também o princípio de secularização inscrito na filosofia da Ilustração como um elemento essencial para que fosse estruturado um imaginário pautado e regulado por preceitos de universalidade, no qual os signos da impessoalidade e da igualdade jurídica pudessem dar 0 tom de emblemas nos quais todos coubessem: "Lei natural, razão, vontade geral, povo etc." (idem, ibid., p. 22). Tratava-se - podemos acrescentar - de incluir, um por um, todos os representantes da espécie no conjunto eqüitativo do gênero humano, tomado agora como cláusula universal. 0 Estado era o maior interessado na formação dos indivíduos, até para que viessem a público os sujeitos mais meritórios; os talentos; as aptidões de cada um - o que conduziria a um aprimoramento geral da sociedade. É sabido que, contudo, nem todos os iluministas pensavam assim (Snyders, 1965). Havia, em Voltaire, ${ }^{4}$ como em outros expoentes da própria E nciclopédia, o medo de que a instrução esparramada por camadas distintas do tecido social desorganizasse os afazeres e os ofícios manuais, prejudicando - com isso a economia pública e fomentando rebeliões políticas. Não havia, nes- 
te sentido, maior desenvolvimento - do ponto de vista dos pensadores iluministas - conferido ao ideal de se proporcionar indistintamente, para todas as crianças em idade escolar, uma equânime oportunidade de acesso à escola. E, principalmente, não existia a perspectiva de uma escola única, em que "a carreira fosse aberta ao talento", na proporção do mérito individual. Tal ideário, no curso da Revolução Francesa, será desenvolvido de maneira estruturada e explícita (Hobsbawm, 1981).

\section{Condorcet e a educação para igualdade de oportunidades}

O Marquês de Condorcet - cujo nome era Marie-Jean-AntoineNicolas Caritat - nasceu no dia 17 de setembro de 1743 na Picardia. Era de família nobre, filho de um cavaleiro que foi morto alguns dias após seu nascimento. Estudou no Colégio dos Jesuítas em Reims e posteriormente no Colégio de Navarra em Paris. Como estudante de Filosofia, adquiriu reputação de ser, primeiramente, um grande conhecedor da matemática. Por essa razão, ele distinguiu-se como pioneiro da chamada "matemática social' quando, em 1765, publicou um trabalho que teve, já à época, grande repercussão: D o cálculo integral. A partir daí, ele seria integrado ao ambiente enciclopedista, travando estreito contato com intelectuais como Voltaire, Diderot, D 'Alembert e muitos outros. Foi membro da A cademia de Ciências, na qual sempre contou com o apoio de ilustres representantes do movimento enciclopedista, que admiravam suas reiteradas demonstrações relativas à suposta possibilidade de estruturar o conhecimento do homem como se de uma matemática social se tratasse. Na época, o intuito de Condorcet era o de unir as chamadas ciências morais com as ciências físicas. D esde esse período que antecede a irrupção revolucionária - como frisa Buisson - Condorcet era reconhecido pela predileção - que sempre o caracterizou - para pensar a situação "dos pobres, dos ignorantes, das vítimas do Antigo Regime; em uma palavra, do povo" (Buisson, 1929, p. 4).

Como matemático, Condorcet dedicou-se a estudar os procedimentos eleitorais em todos os seus níveis. A idéia de revisão constitucional, por exemplo, é de sua autoria: posto que ele compreendia que o progresso no conhecimento dos homens e das coisas exige que, periodicamente, as leis sejam revisadas, em direção ao aperfeiçoamento coletivo do povo. Como estudioso da sociedade, Condorcet "ataca todos os abusos, por uma grande quantidade de brochuras, em sua 
maior parte anônimas, por escritos assinados por pseudônimos diferentes e, sobretudo, por intervenções reiteradas na imprensa e na tribuna de várias sociedades das quais ele fazia parte" (idem, ibid., p. $6)$. Nesse aspecto, pode-se dizer que Condorcet compreendia a instrução - como Diderot - por seu papel de esclarecimento, como privilegiada estratégia formadora de códigos de civilidade e, principalmente, de registros de civilização. Pode-se valer, para comentar 0 pensamento pedagógico de Condorcet, da observação de Francisque Vial: "Para ele, democracia e educação se supõem e se chamam. Ele não concebia que a democracia poderia ser outra coisa além do reino soberano sobre os espíritos da ciência e da razão; e reciprocamente ele só concebia que uma educação racional largamente expandida poderia produzir os frutos do amor à igualdade, à justiça e à liberdade, quais sejam, as virtudes democráticas por excelência” (Vial, 1970, p. 120). O conhecimento traria uma característica emancipatória posta na formação da consciência livre; do sujeito capaz de pensar por si mesmo, sem o recurso à razão alheia. Nesse esquadro, a instrução pública seria estratégia dos poderes seculares dirigida a promover a eqüidade, a razão autônoma e o primado da diferença de talentos sobre a diferença de fortunas.

Quando Condorcet é nomeado presidente do Comitê de Instrução Pública da A ssembléia L egislativa Francesa, ele percebe ali a oportunidade de elaborar um traçado de escolarização capaz de, por um lado, fazer justiça para as camadas menos privilegiadas da população, e ser, ao mesmo tempo, racionalmente projetado. Isso conduziria, progressivamente, à equalização das oportunidades de acesso à escola, e, por decorrência, a uma diminuição, na ordem social, de clivagens postas pela desigualdade de fortunas. Tal projeto - do ponto de vista ilustrado que motivava o Relatório idealizado por Condorcet - conduziria ao aperfeiçoamento do espírito humano. O Plano de Instrução $\mathrm{N}$ acional projetado pela Assembléia Legislativa em 1792 teria - como comenta Francisque Vial - pequena repercussão naquela oportunidade. Foi lido à Assembléia Legislativa e, embora não tenha sido "nem discutido, nem aplicado, exerceu muita influência sobre os projetos que foram elaborados e votados na Convenção" (idem, ibid., p. 6). Posteriormente, no século XIX, o mesmo plano seria alçado - pelo empenho de Jules Ferry na III República Francesa - como uma referência transnacional, pautando, como modelo, projetos e parâmetros reformadores da instrução pública nos mais variados países do continente europeu (e, inclusive, na América Latina - muito particularmente no Brasil). Pelo ideal que 
norteava o Relatório que passaremos, em seguida, a apresentar e a comentar, foram deflagrados significativos esforços de reformas que, nos séculos XIX e XX, caminhavam em direção à constituição de uma escolarização laica, gratuita, pública, para ambos os sexos e universalizada - para todas as crianças.

Quando Condorcet, em 20 e 21 de abril de 1792, lê, para a Assembléia Nacional, o Relatório produzido pelo Comitê de Instrução Pública, o plano não obteve o debate que mereceria. Segundo Cahen estavam todos preocupados com a iminente declaração da guerra e "era necessário organizar a defesa do território (...) E, com efeito, o trabalho imenso do Comitê resultou vão naquele momento: a Legislativa, a despeito de considerar muito razoáveis as intenções do texto, não encontrou oportunidade de discutir o Relatório que lhe era apresentado" (Cahen, 1970, p. 379). A Assembléia haveria, na ocasião, inclusive, solicitado do Comitê uma estimativa de custos que, posteriormente, não chegou sequer a ser analisada. Tratava-se, naquele momento, de saber 0 que fazer com o Rei, com a instituição da monarquia e com o curso dos fatos na política da Revolução.

O tema da instrução pública perpassava, porém, as discussões, por meio do imaginário que procurava antever o homem novo a ser engendrado para aquela pátria que se desejava liberta dos males daquilo que passou a ser, então, nomeado "Antigo Regime”. A idéia motriz do plano que teve redação de Condorcet era a de buscar, pela arquitetura institucional de um modelo articulado de instrução pública, obter progressivamente a minimização das desigualdades produzidas pelo artifício humano, pela concomitante promoção da única desigualdade natural e, portanto, legítima: a desigualdade de talentos - dos dons, das aptidões, dos potenciais, enfim, das capacidades de cada um perante os demais. A preparação cultural acentuaria a força meritória dos mais capazes, o que era, por si, um elemento corretor dos próprios embaraços de uma sociedade liberal, que tinha em mente assegurar, com firmeza, o direito à propriedade, e, portanto, à herança.

Francisque Vial acentua o caráter pioneiro do plano de Condorcet na estruturação de projetos posteriores de instrução pública, que pensavam o tema da universalidade do acesso como correlato do princípio de uma mesma instrução - escola única - para todos. Diz o autor:

Isso significa dizer que Condorcet "filosofou" - para seguir um tema da moda - a pedagogia. Pode-se destacar diretamente essa característica; a qual nos parece melhor demarcar a verdadeira originalidade de Condorcet. Nós 
não o vemos apenas como o autor de um Plano de Instruçao Pública ao qual 0 século XIX fez largos empréstimos. Em nosso entendimento, seu melhor e mais durável título de glória advém de ele haver sido, em nosso país, o verdadeiro teórico da educação nacional (...) o promotor da educação laica, 0 "doutor" da pedagogia democrática e liberal. Assinalando como ideal educativo o próprio ideal de nossa sociedade republicana e democrática, ele fixou verdadeiros princípios de educação moderna; ele lhe ofereceu uma clara consciência de seus fins e de seu objeto e lhe ofereceu uma doutrina. 0 Plano de instrução pública que ele traçou (...) foi e será incessantemente corrigido e aprimorado; a doutrina, naquilo que ela tem de essencial, permanece intacta. (Vial, 1970, p. 18-19)

O que Vial aqui chama de doutrina reside no ideário democrático-liberal de uma escola pública universal, única, laica, gratuita, para ambos os sexos, em todos os seus níveis. Penso que, nos tempos que correm, quando ressurge o espectro do ensino pago nas universidades públicas brasileiras - em nome (ou sem o nome) de um suposto neoliberalismo - é importante recordar um dos projetos que maior impacto obteve para o estabelecimento do programa educativo do liberalismo original - o qual, em sua gênese, possuía, em alguma medida, matizes bastante democráticos. A razão de ser da gratuidade no ensino universitário público reside na lógica interna à idéia de "rede" que entrelaça a íntegra da escolarização. No nível superior chegam os mais talentosos; e estes - independentemente de sua origem de classe e sem que essa variável seja sequer considerada, a bem da universalidade do projeto - deverão ser custeados pelo Estado para, posteriormente, contribuírem, com seu trabalho e com seu mérito, no sentido de aperfeiçoar a si próprios e à nação - e, com isso, promover o bem comum e a felicidade em seu verdadeiro espírito público.

\section{O dever público liberal de custear a educação do E stado: promessas de uma revolução inconclusa}

A seguir, procederemos à interpretação da própria letra do texto do famoso Rapport et projet de décret sur l'organisation générale de l'instruction publique, présentés à l'A ssemblée $\mathrm{N}$ ationale, au nom du $\mathrm{C}_{0}$ mité d'Instruction Publique, par Condorcet, D éputé du D épartement de Paris, lido na tribuna entre os dias 20 e 21 de abril de $1792 .^{5}$

O Relatório trazia por propósito primeiro o de assegurar um bem-estar coletivo, que só poderia ser obtido mediante o desenvolvimento dos potenciais individuais. Sendo assim, a instrução pública 
teria por objeto a idéia da partilha do conhecimento como estratégia para ampliar a felicidade individual e, portanto, coletiva dos cidadãos, a partir do pressuposto de que o esclarecimento das Luzes seria necessariamente fonte de prosperidade comum. Nos termos do relato:

Cultivar, enfim, em cada geração, as faculdades físicas, intelectuais e morais e contribuir dessa forma para o aperfeiçoamento geral e progressivo da espécie humana, derradeira meta a que deve visar toda a instituição social, tal será ainda o objetivo da instrução e este é, para o poder público, um dever imposto pelo interesse comum da sociedade e pelo da Humanidade inteira. (Condorcet, 1943, p. 6)

O plano de organização das escolas deveria, nos termos do Re latório da Assembléia Legislativa, "tornar a educação, não só tão igual e tão universal, mas também tão completa como as circunstâncias 0 permitam" (idem, ibid., p. 7); todos deveriam receber igualmente 0 máximo de instrução que a sociedade pudesse comportar naquelas circunstâncias historicamente dadas, de modo que, progressivamente, 0 conhecimento fosse espraiado, com cada vez maior intensidade, para um conjunto mais amplo de pessoas. A idéia do projeto era, inclusive, a de estabelecer uma orientação metódica e sistemática para que a instrução se derramasse também sobre os indivíduos que, com idade mais avançada, já houvessem deixado a escola. Por isso, previa-se, nas escolas primárias, que todos os domingos fossem realizadas conferências públicas voltadas para 0 conjunto dos cidadãos, independentemente de idades. Isso propiciaria uma atualização do saber já apreendido e, mesmo, um aprendizado, em idade mais avançada, daqueles que, eventualmente, não houvessem contado, anteriormente, com suficientes oportunidades de aprendizado. ${ }^{6}$

A premissa que referenciava o plano de educação dos legisladores franceses trazia a marca da escola única e universal como o grande emblema de regeneração e de emancipação do povo pela revolução. Tratava-se de dar conteúdo simbólico às subjetividades revolucionárias, as quais haviam lançado à luz a bandeira da eqüidade; pela igualdade das oportunidades sociais. Tal intuito deveria consubstanciar-se na organização de políticas públicas; muito especialmente das políticas públicas da escolarização:

Entendemos que o poder público devia dizer aos cidadãos pobres: a fortuna de vossos pais apenas pôde proporcionar-vos os conhecimentos mais indispensáveis; mas asseguram-se-vos os meios fáceis de os conservar e ampliar. Se a natureza vos deu talento, podeis desenvolvêlo, a fim de que não se perca, 
nem para vós nem para a pátria. A ssim, a instrução deve ser universal, isto é, estender-se a todos os cidadãos. D eve ser repartida com toda a igualdade que permitam os limites necessários do orçamento, a distribuição dos homens pelo território e o tempo mais ou menos longo que as crianças puderem consagrar-lhe. Nos seus diversos graus, ela deve abraçar o sistema completo do saber humano e assegurar aos homens, em todas as idades, a facilidade de conservarem os seus conhecimentos e de adquirirem outros novos. Enfim, nenhum poder público deve ter autoridade, nem mesmo direito, de impedir o desenvolvimento de verdades novas, ou o ensino de teorias contrárias a uma política de partido, ou aos seus interesses particulares. (Condorcet, 1943, p. 9-10)

O ensino seria dividido em escolas primárias, escolas secundárias, institutos, liceus e Sociedade $\mathrm{N}$ acional das Ciências e das A rtes.

$\mathrm{Na}$ escola primária, seriam veiculados os conhecimentos gerais, necessários para criar a autonomia individual que faculta ao sujeito dirigir, ele mesmo, sua própria vida, seus afazeres e sua visão de mundo. Tratavase, em suma, de oferecer as habilidades primeiras do ler, escrever e contar. D everia existir uma escola primária para cada agrupamento de 4.000 habitantes. É preciso compreender que cada escola correspondia, na época, a um professor. Além dos rudimentos da leitura, escrita e aritmética, é importante destacar que esse ensino elementar se destinaria também ao aprendizado dos novos critérios de mensuração criados no movimento revolucionário; instrumentos oficiais para pesos e medidas (que, até então, não possuíam qualquer padronização, dificultando, inclusive, as operações contábeis e as trocas comerciais). A escola primária deveria ensinar, pois, o sistema métrico-decimal, estipulado pelos revolucionários franceses com o fito de padronização dos parâmetros de mensuração. Além disso, a escolarização - nesse seu primeiro degrau - proporcionaria uma descrição sumária dos produtos do país, uma explicação sobre as leis nacionais, de maneira que se preparasse a vida em sociedade, no que toca aos deveres e aos direitos que todos temos para com os outros e para conosco. Enfim, o ensino primário deveria supor o "desenvolvimento das primeiras idéias morais e das regras de conduta que delas derivam; finalmente, os princípios de ordem social que possam colocar-se ao alcance da inteligência infantil" (Condorcet, 1943, p. 12). A preocupação com a cidadania também era explícita, e evidenciava-se com a sugestão de que se organizassem festas nacionais, consagrando a memória da Revolução. Como destaca a análise de Bronislaw Baczko, em suas L umières de l'utopie, existiria explicitamente uma intenção pedagógica na festa cívica: a encenação do espetáculo que faria recordar os feitos da revolução; pondo termo, portanto, ao próprio curso revolucionário, mas eternizando seu efei- 
to catártico. ${ }^{7}$ o objeto explícito da escolarização, para além do ensino das ciências, era o de preparar o jovem para alguma rota profissional. Neste sentido, haveria, inclusive, algum tipo de incentivo "para a assiduidade, para o amor ao trabalho, até mesmo para a bondade" (Condorcet, 1943, p. 55), daqueles que eram criteriosamente preparados para se tornarem os futuros trabalhadores e cidadãos da pátria francesa.

Tratava-se de transformar a opinião compartilhada em um espírito público mais elevado. As crianças escolares eram os protagonistas da própria educação; mas contribuiriam também para formar a subjetividade das famílias, no sentido de inscrever e tomar como dado de realidade 0 vértice revolucionário. Milton Meira do Nascimento aborda esse universo mental que tinha na transformação da opinião pública uma referência de inflexão. Soberano agora era o povo; e era assim que ele deveria se reconhecer. A formação da opinião pública, que se apresentava, freqüentemente, pelo seu matiz didático-pedagógico, conduzia os intelectuais orgânicos da Revolução Francesa a se postarem como arautos da verdade revolucionária, da interpretação histórica e da orientação do futuro nacional. Diz Nascimento, sobre o tema, o seguinte: "O que está implícito nesta questão é que o povo, para exercer o poder de vigilância, sem cometer enganos e injustiças, precisa estar muito bem esclarecido. A pergunta de como exercer 0 poder de vigilância vem, pois, acompanhada de uma outra, a de como tornar o povo esclarecido" (Nascimento, 1989, p. 122).

O Relatório recomendava que se compusessem livros específicos para uso das escolas: "Nas esoolas primárias e secundárias, os livros elementares serão o resultado dum concurso com vontade de contribuir para a instrução pública; mas escolher-se-iam os autores dos livros elementares para os institutos" (Condorcet, 1943, p. 55). O propósito era o de que homens sábios dos diversos campos do saber viessem a se interessar pela redação de livros elementares, de modo que se pudesse considerar a obra como uma "prova de seu zelo pela instrução pública e pelo progresso da cultura" (idem, ibid., p. 56)..$^{8}$ A proposta era a de que, nos três primeiros graus de ensino (escolas primárias, escolas secundárias, institutos), cumpria ao poder público estabelecer as fronteiras de cada matéria específica a ser ensinada. Como decorrência disso, sugeria-se que fossem estipulados pelo mesmo poder público "os livros que se hão de adotar; mas, nos liceus, onde deve ensinar-se a ciência integral, é o professor que deve escolher 0 método" (idem, ibid., p. 57). ${ }^{9}$

A propósito: Condorcet - que também se caracterizou como um dos veementes defensores da instrução feminina, em todos os seus níveis 
- havia destacado, em outros escritos que, se o dever de igualdade requeria que as mulheres compartilhassem da mesma instrução oferecida aos homens, caberia à sociedade pensar no papel que o conhecimento poderia ter na vida da mulher. Evidentemente a instrução feminina teria por função primeira a boa educação das crianças às quais, como mães, elas se dedicariam. Mas Condorcet não justifica por aí o direito feminino ao conhecimento: tratava-se de uma dedução lógica do princípio da natureza - que quis todos iguais e que distribuiu com seus próprios critérios (naturais) os talentos, independentemente de fortunas, independentemente de privilégios de castas e independentemente do gênero. Condorcet defendia as mulheres, talvez, por razões lógicas. Mas o que fazer com as mulheres instruídas nas escolas? Já que elas deveriam manter-se no lar disso Condorcet não abria mão - , a vida da mulher deveria voltar-se para alguma coisa mais instrutiva e enriquecedora que os meros afazeres domésticos. Por essa razão, Condorcet já sugerira, algures, que às mulheres fosse confiada a redação de livros dedicados ao ensino elementar, embora isso não conste do Relatório do Comitê de Instrução Pública. ${ }^{10}$

Havia, no texto do Comitê de Instrução Pública da A ssembléia L egislativa Francesa, sob a liderança de Condorcet, o pleno reconhecimento de que o nível primário de ensino seria o único, nas condições então presentes, que poderia ser, de fato, estendido à totalidade dos cidadãos. Mas a idéia era justamente a de que, gradativamente, essa oportunidade de acesso à escola fosse alargada, de maneira que, cada vez mais, um contingente sempre mais amplo de crianças pudesse alçar um degrau a mais na instrução nacional. Por essa razão, a escola deveria ser gratuita em todos os graus, embora, no princípio, apenas a escola primária tivesse condições de ser universalizada para todo solo francês. $\mathrm{O}$ texto reconhece os limites postos pelas condições objetivas historicamente dadas; obstáculos esses que deveriam ser, com o tempo, progressivamente corrigidos e transpostos:

(...) seria fácil alargá-los quando a melhoria das condições de vida do povo, a distribuição mais eqüitativa das fortunas, conseqüência necessária das leis, e os progressos dos métodos de ensino tenham feito chegar o momento oportuno; quando, enfim, a diminuição da dívida e dos gastos supérfluos permita consagrar a fins verdadeiramente úteis uma porção maior das receitas públicas. (Condorcet, 1943, p. 17).

Uma escola secundária ${ }^{11}$ seria criada para cada distrito com população equivalente a 4.000 habitantes. A princípio, sabia-se que freqüentariam esse segundo degrau de instrução apenas as crianças cujas famílias pudessem prescindir de tempo e de recursos. A instru- 
ção em todos os graus era gratuita; esta segunda etapa deveria estar contida no cômputo do ensino universal. Contudo, o relator reconhece que nem todos os filhos de camponeses ou de artífices poderiam, naquela altura, ser encaminhados à escola, pelas próprias exigências das famílias quanto ao trabalho precoce da meninice. De qualquer modo, as crianças que pudessem continuar seus estudos teriam seu espírito aguçado, o que favoreceria a formação de um verdadeiro espírito público e 0 gosto efetivo pelo trabalho. 0 ensino secundário prepararia 0 sujeito para acompanhar o desenvolvimento das manufaturas e para lidar criativamente com as novas exigências de saber postas por tais transformações nas tecnologias de produção. ${ }^{12} \mathrm{O}$ ensino - em movimento contrário à tendência que apontava para o trabalho mecânico do homem refém da maquinaria - traria infindáveis renovações: "Porque terá por objeto, quer processos novos de agricultura ou de artes mecânicas, observações e novos detalhes, quer a exposição das leis gerais, à medida que sejam promulgadas, e 0 desenvolvimento das operações de governo, quando sejam dum interesse universal" (idem, ibid., p. 21).

0 terceiro grau de instrução aconteceria nos chamados institutos (correspondentes, talvez, ao nosso nível de Ensino Médio), onde o saber erudito deveria ser suficientemente desenvolvido para capacitar os indivíduos para o "desempenho das funções públicas que exigem mais conhecimentos" (idem, ibid., p. 23). As matérias de estudo ali ministradas confeririam, por suposto, um repertório suficiente e a imprescindível abertura intelectual para o estudo aprofundado. Mas como classificar essas ramificações da árvore do conhecimento? Condorcet também se colocava claramente a questão em seu Relatório. Era difícil distribuir as ciências e as artes, até porque não haveria uma proporção equiitativa entre os professores; sendo algumas matérias de domínio mais comum que outras, a despeito de sua importância intrínseca. Para classificar o saber, era recomendável discriminar a especificidade de cada uma de suas ramificações; nos seguintes aspectos:

Poreis, sem dúvida, o conhecimento dos homens na classe que afeta a memória; colocareis, depois, a história natural ao lado da história das nações e o estudo das artes junto ao estudo das línguas; separá-los-ei da química, da política, da física e da análise metafísica, ciências às quais estão ligados estes conhecimentos dos fatos, pela natureza das coisas e pelos próprios métodos de as tratar. Tomar-se-á por base a natureza dos objetos? Mas o mesmo objeto, conforme a maneira de o considerar, pertence a ciências inteiramente distintas. Essas ciências, assim classificadas, exigem qualidades especiais que a mesma pessoa raramente reúne. Teria sido difícil encontrar e porventura formar 
homens em estado de se adaptarem a estas divisões do ensino. As mesmas ciências não se refeririam às mesmas profissões, as suas partes não inspirariam igual interesse aos mesmos espíritos e estas divisões acabariam por fatigar professores e alunos. Q ualquer outra base filosófica que se escolhesse encontrarse-ia sempre embaraçada por obstáculos do mesmo gênero. Por outro lado, seria preciso dar a cada divisão uma certa extensão e manter entre elas uma espécie de equilíbrio. O ra, numa divisão filosófica, só seria possível chegar a isto reunindo pelo ensino o que houvesse sido separado pela classificação. Havemos, pois, imitado, em nossas distribuições, a marcha que o espírito humano tem seguido nas suas indagações, sem pretender sujeitá-la a tomar outra, de harmonia com a que nós mesmos daríamos ao ensino. (Condorcet, 1943, p. 25-26)

O ensino das ciências era considerado um antídoto contra os preconceitos, as superstições e qualquer forma de obscurantismo. Condorcet acreditava firmemente no progresso do espírito humano, na marcha da civilização contra a ignorância. Esse movimento em direção ao esclarecimento seria, para ele, fonte de prosperidade coletiva e de aprimoramento social. Como Iluminista, Condorcet via a caminhada do homem em direção à sua perfectibilidade como uma vocação do próprio gênero humano. Por isso, ele era otimista para projetar o que alguns qualificaram como "matemática social". ${ }^{13} \mathrm{~A}$ educação escolar deveria dirigir-se à busca da verdade - e para isso seria voltada para o aprendizado da história, das línguas e das, assim nomeadas, ciências morais. Condorcet posta-se incisivamente contrário à feição política da oratória como arte de sedução dos corações e das paixõ̃es do homem. Compete ao sujeito instruído escutar exclusivamente a voz de sua racionalidade. Formar para a cidadania era precaver o cidadão também contra o uso eloqüente e, por vezes, nefasto da retórica: "Os representantes do povo que, seduzidos por um orador, cedessem a outra força que não fosse a sua razão, atraiçoariam o seu dever, pois que decidiriam sobre interesses de outrem e perderiam bem depressa a confiança pública na qual exclusivamente está apoiada toda a constituição representativa" (idem, ibid., p. 33).

Condorcet defendia o estudo meticuloso da legislação, sem, contudo, que o conhecimento daí advindo contribuísse para obscurecer a necessidade social de que a própria legislação fosse revisada, modificada, aprimorada. Na trilha do pensamento contratualista e do liberalismo clássico, o Relatório declara a existência de direitos de natureza - "princípios de justiça natural" - , direitos esses "essenciais do homem, dos quais as leis não são mais do que a razão, o desenvolvimento ou as aplicações" (Condorcet, 1943, p. 36). ${ }^{14}$ A "marcha do 
espírito humano" em direção à perfectibilidade não admitiria o retrocesso; nem mesmo qualquer regresso. A reforma das leis deveria estar prevista exatamente para que, periodicamente, fossem submetidos à crítica os preceitos legais, com o fito de criteriosamente verificar se estes ainda eram válidos para a prosperidade pública. Tudo - inclusive as leis - deveria ser posto ao debate público. Condorcet não admitia "que nenhum sistema de organização social fosse oferecido ao entusiasmo ou aos preconceitos, como objeto dum culto supersticioso, mas que todos fossem apresentados à razão, como combinações diversas, entre as quais haja o direito de escolher" (idem, ibid., p. 86). Não se aceitava, em hipótese alguma, o que o texto qualificava de "respeito supersticioso pelas leis existentes" (idem, ibid., p. 84). Buscava-se - isso sim - a possibilidade de "existirem conjuntamente a submissão voluntária às leis e o ensino dos meios de corrigir os seus defeitos e de retificar os seus erros, sem que a liberdade de opiniões prejudique a ordem pública, sem que o respeito pela lei encarcere os espíritos nem detenha o progresso dos conhecimentos ou consagre erros" (idem, ibid.).

Como sublinha argutamente Paul Bastide, ao passo que Comte - valendo-se posteriormente do suporte teórico da Ilustração - compreendia na educação uma estratégia coletiva para tomada de consciência dos deveres de ordem, de hierarquia e de subordinação, Condorcet - pelo contrário - tomava a ação pedagógica como um recurso privilegiado para promover a eqüidade, com vistas ao estabelecimento da única desigualdade legítima entre os homens: aquela que vem pela natureza, a dos talentos; e que resulta, portanto, em um patamar a mais de justiça e de equilíbrio natural (Bastide, 1957, p. 608). Promover o talento, pelo mérito, significava, no limite, contrabalançar a desigualdade das fortunas - esta sim - , artificial. ${ }^{15}$ Condorcet tinha na acepção de perfectibilidade a compreensão do contributo oferecido por cada geração para integrar o patrimônio como do gênero humano. Não haveria ordem, regra, nem mesmo qualquer lei que pudesse, sob tal prisma, ser considerada imutável ou inamovível. Não haveria limite para o aperfeiçoamento humano, assim como não há limite para demarcar o máximo possível de liberdade e de igualdade. Eram apenas ideais reguladores...

Jamais um povo gozará duma liberdade constante e segura, se a instrução nas ciências políticas não for geral e independente de todas as instituiç̃ões sociais, se 0 entusiasmo que exciteis na alma do cidadão não for dirigido pela razão, se puder nutrir-se de outra coisa que não seja a verdade, se, ligando 0 
homem pelo hábito, pela imaginação e pelo sentimento à sua constituição, às suas leis e à sua liberdade, não lhe preparais, mediante uma instrução geral, os meios de chegar a uma constituição mais perfeita, de se conferir melhores leis e de atingir uma liberdade mais completa. Porque acontece com a liberdade, com a igualdade e com os grandes objetos das meditações políticas o mesmo que acontece com os das outras ciências: existe na ordem das coisas possíveis um último termo, do qual a natureza quis que possamos aproximar-nos constantemente, mas que nos proíbe alcançar jamais. (Condorcet, 1943, p. 37)

No que toca ao ensino superior, o Relatório não se refere, no sentido terminológico, a universidades; prefere nomear liceus ao quarto grau de instrução: esses estabelecimentos destinados à produção e divulgação do conhecimento erudito - "todas as ciências são aí ensinadas, no seu pleno desenvolvimento" (idem, ibid., p. 45). Nos liceus haveria a tarefa imprescindível de preservação e irradiação do conhecimento em seu sentido pleno - "cada geração pode transmitir à seguinte o que recebeu da anterior e o que ela mesma pôde acumular" (idem, ibid.). Eram previstos, a princípio, nove liceus, que deveriam ser estruturados para formar sábios e professores. Tais liceus ficariam distantes uns dos outros, situados em regiões estratégicas do território francês, de maneira que pudessem abrigar jovens provenientes das mais distintas regiões, independentemente, inclusive, da riqueza de cada um dos específicos distritos onde eles se situassem.

O Relatório de Condorcet é incisivo ao afirmar a total laicidade e gratuidade de todos os graus do ensino, a despeito do fato de não ser ainda possível, na época, estender a todas as crianças a possibilidade de seguir to do o percurso da escolarização. $O$ ensino dos liceus revelaria, pela própria composição de seu corpo de professores e de estudantes, uma progressiva diminuição da desigualdade de fortunas, unindo sujeitos provenientes de variadas camadas da sociedade. Caso 0 ensino - mesmo aquele dos liceus - não fosse gratuito para todos os alunos, independentemente de suas específicas extrações familiares, seria fácil calcular as distorções que ocorreriam. Neste sentido - como já se observou anteriormente - o relato de Condorcet é absolutamente explícito na intransigente defesa da gratuidade em todos os níveis da instrução pública oferecida:

As cidades ricas e as regiões férteis teriam todos os professores hábeis e juntariam esta vantagem a todas as outras. Como existem ramos de ciência, e nem sempre os menos úteis, que exigirão um concurso mais fácil, seria preciso estabelecer diferença nos ordenados dos professores, ou deixar subsistir, entre 
eles, uma desigualdade excessiva que prejudicaria aquela espécie de equilíbrio entre os diversos ramos de conhecimentos humanos, tão necessários aos seus progressos reais (....) Por outro lado, visto que é preciso pagar ordenados fixos aos professores, e que a contribuição que se exigiria dos alunos deveria ser necessariamente muito pequena, sê-lo-ia também a economia e o gasto voluntário que daqui resultaria cairia menos sobre as famílias opulentas que sobre aquelas que se impõem sacrifícios para dar aos filhos, cujos primeiros anos revelaram talento, os meios de os cultivarem e utilizarem para a sua fortuna. Enfim, a emulação que faria nascer entre os professores o desejo de multiplicar os alunos, cujo número aumentaria os seus proventos, não obedece a sentimento bastante elevado para que se possa lamentar a sua ausência. Não seria para temer que resultassem bem mais rivalidades entre os centros de ensino; que os professores antes procurassem brilhar do que instruir; que o seu método e as suas opiniões fossem calculadas apenas seguindo o desejo de atrair a si um maior número de alunos; que cedessem ao temor de os afastar, combatendo certos prejuízos e manifestando-se contra certos interesses? (Condorcet, 1943, p. 54)

A opinião comum era tida por inimiga da instrução. Os homens de saber erudito não se deveriam curvar perante sua força ou obedecê-la; pelo contrário, caberia a eles corrigi-la, formá-la e, sobretudo, para utilizar o termo de Condorcet, "antecipar-se a ela" (idem, ibid.). Existiria uma voz e um lugar privilegiado para a interpretação do curso da história. Seriam os homens de letras aqueles que ofereceriam a interpretação autorizada para estabelecer os protocolos do relato revolucionário. A instrução pública era um contributo precioso para fornecer a civilidade, a sociabilidade e até mesmo a sensibilidade revolucionária (Vovelle, 1985).

Condorcet projeta, inclusive com cálculos supostamente estatísticos, a situação francesa no momento em que o projeto da Assembléia Legislativa viesse, eventualmente, a ser adotado: todos os anos, dentre cada 3.500 crianças escolares, 1.000 chegariam até o grau de instrução oferecido pelos institutos; desses, 600 atingiriam a etapa dos liceus; e, finalmente, 400 concluiriam este nível de ensino.

No trajeto da escolarização, em uma sociedade onde, por princípio, todos eram iguais, seriam os mais talentosos a galgar os degraus mais elevados da instrução. Por essa razão, o domínio da rede pública de escolarização não estaria posto em nenhum mecanismo particular ou expressamente controlado pelo Estado. Haveria uma Sociedade N acional das Ciências e das A rtes que garantiria, ao mesmo tempo, a independência do ensino perante os poderes de Estado e perante as pressões eventuais advindas das forças políticas e econômicas. Tal So- 
ciedade deveria ser composta exclusivamente por sujeitos reconhecidamente sábios em alguma área do saber humano: "Homens que abraçaram uma ciência em toda a sua extensão e a penetraram em toda a sua profundidade, ou que a enriqueceram com as suas descobertas" (Condorcet, 1943, p. 79).

No topo daquilo que se estruturava como uma pirâmide da instrução popular, haveria, nos termos do relato, a referida instância suprema: a Sociedade $\mathrm{N}$ acional das Ciências e das A rtes, que atuaria como elemento aglutinador dos progressos do conhecimento e como um espaço de entrelaçamento criativo e criador das diversas ramificações do saber humano. A idéia dessa agremiação era a de proteger a instância das ciências e das artes contra os possíveis inimigos das Luzes e, eventualmente, contra o próprio arbítrio do Estado. Tratava-se de um órgão da sociedade civil que se pretendia constituir: controlado pelos indivíduos ligados às letras, à filosofia, às ciências, às artes enfim, ligados ao progresso do conhecimento. Para a formação das opiniões do homem comum, ela era o esboço de um espírito público ao mesmo tempo arguto e responsável. Intérprete das visões de mundo dos homens ilustrados, essa Sociedade protegeria o tecido social contra o charlatanismo, contra a ignorância e contra possíveis abusos dos poderes instituídos. ${ }^{16}$ Nos termos de seu relator:

Uma sociedade ocupada duma só ciência vê-se muito facilmente arrastada a contrair um espíito particularista e a converter-se numa espécie de corporação. Enfim, importa ao serviço da ciência aproximar e não dividir aquelas que se relacionam, em alguns pontos. Enquanto cada uma faz progressos e se enriquece com descobertas que lhe são próprias, estes pontos de contato se multiplicam e estas aplicações duma ciência à outra oferecem uma colheita fecunda em descobertas úteis; e tal deve ser o efeito do acréscimo de cultura, que, dentro em breve, nenhuma ciência estarájá isolada, nem será totalmente estranha às outras. Foi de harmonia com estes pontos que formamos a divisória da Sociedade Nacional. (Condorcet, 1943, p. 59-60)

O conhecimento academicamente produzido seria, dessa maneira, didaticamente divulgado e propagado pelos diversos níveis de ensino ministrado. As sessões de apresentação de trabalhos e debate de teses acadêmicas da Sociedade $\mathrm{N}$ acional das Ciências e das A rtes seriam abertas ao público, embora sem qualquer preocupação em fazer descer a ciência ao nível do conhecimento comum:

Estarão abertas ao público, mas somente para que aqueles que cultivam as ciências possam escutar as leituras e seguir as discussões e sem que a necessida- 
de de se fazer ouvir pelos espectadores, de se pôr ao seu alcance, de os interessar ou de os divertir, influa sobre a ordem das sessões, a forma da discussão ou a escolha das leituras. (idem, ibid., p. 66)

Cabia à Sociedade N acional das Ciências e das A rtes a supervisão de todos os demais níveis de ensino; e, para tanto, ela gozava de alguma autonomia perante o poder público. Os membros da Sociedade $\mathrm{N}$ acional - como costumava já ocorrer no seio das academias então existentes - escolheriam eles mesmos seus pares. Além de elegeremse, portanto, a si próprios, tinham por tarefa a de também eleger os professores dos liceus, pelo fato de serem estes os encarregados diretos do ensino das ciências desenvolvidas pelos próprios acadêmicos da Sociedade $\mathrm{N}$ acional. Por sua vez, os professores dos institutos seriam nomeados pelos professores dos liceus. 0 argumento do Relatório, para justificar tais procedimentos, era o de que "a razão exige que os homens encarregados de instruir as crianças ou os cidadãos sejam escolhidos por aqueles que se pode supor terem conhecimentos iguais ou superiores" (idem, ibid., p. 76). Pretendia-se, pois, que cada degrau de ensino fosse estruturado, regulado e inspecionado pelo nível imediatamente superior:

Q uanto aos professores das escolas primárias e secundárias, a lista dos elegíveis será formada pelos professores dos institutos do distrito, e a eleição pertencerá, para os primeiros, à corporação municipal do lugar em que exista a escola e, para os últimos, à assembléia dos pais de família do respectivo distrito. Com efeito, tanto os professores do ensino secundário como os do ensino primário devem ter a garantia de que os corpos administrativos não podem ser seus juízes e de que eles não serão apreciados, senão por homens em que haja o direito de supor uma maior instrução. A lista dos elegíveis, que comprove a sua capacidade, deve ser formada pelos membros dum estabelecimento superior. Mas, se na escolha dum professor secundário entre os elegíveis, é necessário preferir o mais sabedor e competente, na dum professor primário, cujos alunos são mais jovens e em que influem muito mais as qualidades morais do professor, em que se trata apenas de ensinar conhecimentos muito elementares, deve-se tomar por guia a opinião das pessoas que a Natureza encarregou de velar pela felicidade da geração nascente, ou, pelo menos, dos seus mais imediatos representantes. (...) Pelos diretórios formados na Sociedade $\mathrm{N}$ acional, os liceus e os institutos serão encarregados da inspeção habitual dos estabelecimentos inferiores. Em casos importantes, a decisão caberá a uma das classes da Sociedade $\mathrm{N}$ acional, ou à assembléia dos professores, quer dos liceus, quer dos institutos. Por este meio será garantida a independência da instrução, e a inspeção não exigirá a criação dum estabelecimento particular, em que se possa temer o espírito de domínio. (Condorcet, 1943, p. 72-74) 
Previa-se que a estrutura "em rede" da educação pública nacional pudesse fazer frente a quaisquer forças e poderes estranhos a ela, e que significassem, eventualmente, ameaça ou abuso contra 0 avanço da sociedade. A coletividade e a história, em seu trajeto de incessante aperfeiçoamento, não admitiriam recuos. A independência almejada para todos os níveis de instrução não era, contudo, alheia à autoridade dos homens ilustrados, cujo parecer deveria ser sempre consultado, já que, à sabedoria, não se pode jamais resistir, sem comprometer a responsabilidade perante a busca da verdade.

Condorcet conclui o relato dizendo que o plano projetado havia sido elaborado tomando por referência "0 estado atual da cultura na França e na Europa" (idem, ibid., p. 86). Tratava-se, pois, de uma prospecção que, extrapolando as fronteiras nacionais, justificava-se na agenda do firmamento dos Estados Nacionais cidadãos e democráticos. D o ponto de vista da filosofia da história implícito a tal concepção, tratava-se de providenciar medidas que estivessem de acordo com "a marcha do espírito humano nas ciências e nas artes; enfim, segundo o que pode esperar-se e prever-se destes novos progressos" (idem, ibid., p. 86-87). A interpretação do relato de Condorcet remete-nos, invariavelmente, a pensar em nossa situação contemporânea; na história de nosso tempo presente: no Brasil do princípio do século XXI. Consciente dos riscos de tal ilação, passemos, pois, à diacronia...

A defesa, hoje, da universidade gratuita a partir de seus alicerces de origem

Fernando Catroga, ao abordar o universo mental expresso pelo conceito conferido à própria idéia de revolução a partir do impacto da Revolução Francesa, destaca a antecipação daquilo que seria a órbita posterior do positivismo e de tantas outras narrativas totalizadoras que se constituíram no século XIX. A construção do saber, visivelmente, passa a ser entrelaçada com 0 propósito da previsão e com a utopia de, prevendo-0, prover o futuro (Catroga, 2003, p. 56). Tratava-se de - por meio do progresso científico, por suas implicações tecnológicas e pela progressiva e planificada multiplicação desse saber - engendrar uma nova acepção de temporalidade, em que a dimensão temporal pudesse ser matematicamente calculada. Tratava-se de uma atualização para os estudos humanos do grande sonho alquímico de uma descoberta para um radical controle da transformação. Podese dizer que Condorcet se inscrevia nessa utopia. 
Catroga julga que a ordenação cultural predominante da modernidade supunha que o projeto da racionalização se estendia a uma compreensão da história que potencializava a própria crença no aperfeiçoamento social impressa nessa mesma razão moderna. Há - diz, com argúcia Catroga - "um desejo de conquista que caracterizará a episteme moderna" (Catroga, 2003, p. 52); episteme essa que se traduz pelo signo da secularização. Q uando Catroga interpreta o parecer de Kant sobre a Revolução Francesa em seu caráter de profecia, de rememoração e de prognóstico de uma razão andarilha para o governo do mundo, a história nos reaparece:

D e fato, foi principalmente após o impacto deste grande acontecimento que revolução envolveu, não só a idéia de futuro, mas também uma releitura do passado, em ordem a ajustá-la à inteligibilidade do devir progressivo da humanidade. D esta convicção promanou a crença na capacidade programadora e planificadora do homem para fazer e acelerar o seu destino, na procura da sua autonomia e auto-emancipação. Por isso, a "revolução" - como outrora 0 cristianismo, reinterpretado à sua luz - constituía como que o início de um "tempo novo" e de um "homem novo", epopéia que, a par de suas concretizações específicas, teria de abranger toda a humanidade (e a humanidade como um todo), qualquer que fosse a palavra que significasse esta extensão (cosmopolitismo, internacionalismo, universalismo), ou o meio a que se recorresse para a pôr em ação (reforma, evolução, revolução violenta). Inscrita num tempo aberto, a "revolução" já realizada, ou a que ainda estava por vir, teria de ser permanente (ela não era o fim, mas, tão-somente, 0 início do fim da história), logo sempre inconclusa, mesmo que esta limitação não fosse percebida pelos seus protagonistas. É que, apesar do voluntarismo planificador que as movia, todas elas mostravam dificuldades em atribuir ao futuro novo que para si mesmo reivindicavam, quando comparavam a luminosidade da sua irrupção com a escuridão do passado que combatiam. D ir-seia que começavam a envelhecer logo no dia do seu próprio nascimento; daí a sua simultânea dimensão épica, utópica e trágica (todas elas tendem a devorar os seus próprios filhos). Parece indubitável que o novo conceito só pôde medrar com a auto-elevação do homem a obreiro da história e com a simultânea radicação de um ideal epistêmico em que, como nas relações entre a ciência e a técnica, reivindicava-se a posse de um saber que faria aumentar o poder sobre as coisas e o dos homens com relação a outros homens. (idem, ibid., p. 88)

Catroga traduz esse movimento como uma inaudita vivência do tempo que, de algum modo, estruturava-se mediante uma concepção de história que era imanente, essencialista e determinista. Curiosamente, a Revolução jamais poderia ser levada a cabo sem que se considerasse o elemento surpresa, os brejeiros passeios do acaso. Mas os 
protagonistas do movimento agiam como se seu traçado teórico ou sua ação prática estivesse inscrita, desde o princípio e como princípio, em um necessário devir, ao qual o futuro apenas deveria fazer jus. Mais uma vez, recorrer às palavras de Catroga parece oportuno: "Em nome de uma essência, de um programa, de um plano, a doutrinação revolucionária mobilizou a história para se credibilizar como novidade, revendo, para isso, o passado em função dos projetos de futuro" (idem, ibid., p. 89).

Correndo o risco de algum anacronismo inevitável em um ensaio como este, poderíamos nos indagar o seguinte: se os revolucionários em França, de fato, justificavam em nome do futuro os projetos que eram postos no presente de sua contemporaneidade, por que não podemos nós remeter nosso presente para esse passado do qual somos todos - para o bem ou para o mal -, em alguma medida, herdeiros?

A utopia de uma escola pública de Estado, hoje direito subjetivo do cidadão, e, portanto, universal, única, gratuita e laica ainda corresponde à pauta de direitos públicos defendida pelos setores mais progressistas da sociedade brasileira. Trata-se, como vimos, de uma proposta cuja origem remonta àquilo que alguns preferem chamar de revolução burguesa. Mesmo assim, nem todas as suas cláusulas têm sido suficientemente compreendidas como partes de uma mecânica mais ampla. A "rede" pública que entrelaça os diferentes níveis da instrução era compreendida como um todo articulado: uma engrenagem conjunta. O ra, se ali estava a gênese da famosa pirâmide escolar - na qual todos teriam o acesso à partida, mas que deixaria progressivamente muitos pelo caminho - , a própria justificativa da depuração residia na lógica liberal de mérito, de talento, de merecimento; a qual se propõe a romper com privilégios estamentais. Pensando assim - do ponto de vista do liberalismo "não neo" - é que todos os cursos mantidos pelo Estado como dever público de políticas sociais deverão ser gratuitos. A universalidade, que se deve garantir nos degraus iniciais, não estaria dada - pelas próprias condições de nossa história do tempo presente - no nível superior. Falta a nós ainda no Brasil de hoje - oferecer a todos a escola de ensino médio. Porém, todos aqueles que chegaram ao último degrau da instrução correspondente, em nosso caso, às universidades e aos cursos superiores custeados e mantidos pelo Estado - recebem, por direito, o ensino gratuito, pelo princípio de que foi pelo mérito que eles chegaram até lá: sejam ricas ou pobres suas famílias; desigualdades outras que devem estar na agenda da tributação. 
Com tudo isso, o que procurei dizer foi que, em nome do princípio da universalidade da instrução, não se pode ferir o preceito da gratuidade sem rasgar e trair as promessas mais generosas do liberalismo clássico. A universidade é pública e gratuita não porque os governantes da hora assim o desejam, mas porque está inscrita em um dado projeto de futuro, em que todos deverão receber oportunidades eqüitativas de desenvolvimento de suas aptidões naturais. Para que as próprias desigualdades de riqueza sejam mantidas, a universalização de políticas públicas deve-se manter como pressuposto e axioma. Pela mesma razão, poder-se-ia questionar qualquer política de quotas para 0 ensino público. Mas aí entraríamos em uma outra discussão. Seja como for, com o perdão do extenso desenvolvimento analítico de um único programa de escolarização, eu recomendaria que revisitássemos os estudos que deram lugar ao pensamento liberal de nossa modernidade, até para fazer frente àqueles que supõem não haver no liberalismo qualquer lugar para as políticas públicas de direitos sociais. D efender a universidade pública e gratuita, defender a autonomia universitária e a liberdade de cátedra, defender as decisões colegiadas das instâncias decisórias, tudo isso estava previsto no Relatório que, nos embates da Revolução Francesa, fez surgir a arquitetura de uma "rede" articulada de instrução pública, custeada pelos poderes do Estado, sem, no entanto, diretamente a eles se submeter. Uma instrução que, voltada para todos, dirige-se ao bem comum. Uma instrução que coloca, de uniforme, todos iguais na escola. Uma instrução que conduz ao pensamento autônomo crítico, livre e criativo. Uma instrução que, enfim, alia-se àquilo que de mais generoso 00 cidente já produziu: 0 sonho de uma sociedade mais livre, mais igual e mais fraterna...

Porque jamais perdemos de vista a doutrina de destruir todos os gêneros de desigualdade, de estreitar, entre os homens que a natureza e as leis adscrevem ao mesmo solo eaos mesmos interesses, relações que façam a sua união mais suave e mais íntima. (Condorcet, 1943, p. 64)

Recebido em julho de 2003 e aprovado em agosto de 2003.

\section{Notas}

1. A perspectiva de Rousseau introduz - a meu ver - alguns elementos inovadores para a reflexão ética do Iluminismo, particularmente 0 entrelaçamento entre o campo do entendimento e alguma consideração sobre as leis morais, que ele traduz como derivadas do sentimento: "Sinto minha alma, conheço-a pelo sentimento e pelo pensamento, sei que é, sem saber qual seja sua essência; não posso raciocinar sobre idéias que não tenho. 0 que eu sei 
bem é que a identidade do eu só se prolonga pela memória e que, para ser o mesmo, efetivamente, é preciso que me lembre de ter sido. O ra, eu não poderia lembrar-me, depois da morte, do que fui durante a vida, sem que me lembre também do que senti, por conseguinte do que fiz; e não duvido que essa recordação faça um dia a felicidade dos bons e 0 tormento dos maus. Neste mundo, mil paixões ardentes absorvem o sentimento interior e substituem-se aos remorsos" (Rousseau, 1979, p. 322).

2. "Se, pois, se fizer a pergunta - Vivemos nós agora numa época esclarecida? - a resposta é: não. Mas vivemos numa época do Iluminismo. Falta ainda muito para que os homens tomados em conjunto, da maneira como as coisas agora estão, se encontrem já numa situação ou nela se possam apenas vir a pôr de, em matéria de religião, se servirem bem e com segurança do seu próprio entendimento, sem a orientação de outrem. Temos apenas claros indícios de que se lhes abre agora o campo em que podem atuar livremente, e diminuem pouco a pouco os obstáculos à ilustração geral, ou a saída dos homens da menoridade de que são culpados. Assim considerada, esta época é a época do Iluminismo" (Kant, 1989, p. 17).

3. "A ignorância é o resultado do escravo e do selvagem. A instrução dá ao homem a dignidade e o escravo começa a sentir que ele não nasceu para a servidão. (...) A instrução ameniza os traços de caráter, esclarece a propósito dos deveres, suaviza os vícios (...) inspira 0 amor da ordem, da justiça e das virtudes e acelera o nascimento do bom gosto em todas as coisas da vida" (Diderot, apud Cahen, 1970, p. 326).

4. Pode-se dizer que, a despeito de suas hesitações diante da ameaça das convulsões sociais possivelmente advindas da universalização da instrução, o parecer de Voltaire sobre o tema da tolerância foi um dos alicerces que possibilitaram, ainda que de maneira algo ambígua, a oportunidade do debate aberto que resultaria, anos mais tarde, na defesa intransigente que os revolucionários de França fizeram, sob a liderança de Condorcet, por uma escola única e universal, oferecida gratuitamente pelo Estado para todas as crianças. Dizia Voltaire que qualquer tipo de intolerância extrapola a fronteira do direito de natureza; com as seguintes palavras: "O direito natural é aquele que a natureza indica a todos os homens. (...) Em todos os casos, o direito humano só pode funcionar nesse direito de natureza; e 0 grande princípio, o princípio universal de ambos é, em toda a terra: 'Não faças a outro o que não gostarias que te fizessem'. Ora, não se percebe como, de acordo com esse princípio, um homem poderia dizer a outro: 'Acredita no que acredito e no que não podes acreditar, ou morrerás'. (...) Se fosse de direito humano conduzir-se dessa forma, caberia então que 0 japonês detestasse 0 chinês, 0 qual execraria o siamês; este perseguiria os gancares, que cairiam sobre os habitantes do Indo; o mongol arrancaria o coração do primeiro malabar que encontrasse; 0 malabar poderia degolar o persa, que poderia massacrar 0 turco - e todos juntos se lançariam sobre os cristãos, que, por muito tempo, devoraram-se uns aos outros. 0 direito à intolerância é, pois, absurdo e bárbaro; é o direito dos tigres, e bem mais horrível, pois os tigres só atacam para comer, enquanto nós exterminamo-nos por parágrafos" (Voltaire, 2000, p. 33-34).

5. Passaremos, de agora em diante, a designar por Relatório o plano elaborado sob a direção de Condorcet na Assembléia Legislativa Francesa de 1792. Nas transcrições, utilizamos a tradução brasileira, referida na seqüência. Mas uma cópia em francês do texto original pode ser localizada na revista E nfance publicada em Paris, em seu tomo 42, n. 4, no ano de 1989.

6. "Continuando assim a instrução durante toda a vida, impedir-se-á que os conhecimentos adquiridos nas escolas se varram rapidamente da memória, manter-se-ão os espíritos numa atividade útil, instruir-se-ão os povos em novas leis, em conhecimentos agrícolas, em métodos domésticos que lhes interessa não ignorar; poder-se-á indicar, enfim, a maneira de se instruírem por eles mesmos, como seja procurando palavras no dicionário, servindo-se do índice dum livro, seguindo narrações ou descrições, notas ou extratos sobre uma carta, um plano ou um desenho. Estes meios de aprender que, numa educação mais extensa, se 
adquirem somente com o hábito, devem ser diretamente ensinados, numa instrução limitada a tempo mais curto e a um pequeno número de lições" (Condorcet, 1943, p. 14).

7. “(...) as festas não traduzem somente uma necessidade real de exprimir uma sensibilidade nova, mas elas são também um instrumento particularmente útil para influenciar e orientar, para impressionar os tolos ou mesmo manipulá-los" (Baczko, 1978, p. 256).

8. Condorcet explica por que preferia que os livros fossem encomendados diretamente às pessoas; e não fossem, como alternativa, colocados a concurso: "Se, pelo contrário, propõe-se um concurso, quem garantirá que se obtenha um bom livro elementar? Como escolher, entre dez obras, por exemplo, o que seria um curso elementar de matemática ou de física, em dois volumes? Teríamos a certeza de que os julgadores suportariam o aborrecimento deste exame, ou de que, suportando-0, julgariam bem? Alguns pontos de vista filosóficos, algumas idéias fixas e engenhosas que observarem numa obra não farão inclinar a balança em seu favor, com prejuízo de método e clareza?" (Condorcet, 1943, p. 56).

9. Vale notar que o Relatório do Comitê nomeou liceus os estabelecimentos de ensino superior que comporiam, de alguma maneira, a estrutura universitária da França.

10. "Talvez fossem elas mais próprias que os homens para dar aos livros elementares métodos e clareza mais dispostas, por sua amável flexibilidade, a adaptar-se ao espírito das crianças, que observaram numa idade menos avançada, e cujo desenvolvimento seguiram com um interesse mais terno" (Condorcet, apud Badinter, 1991, p. 88).

11. Poderíamos dizer - com o perdão do anacronismo - que a estrutura do que Condorcet chamava de escolas primárias e escolas secundárias teria correspondência nos dois níveis sobrepostos ( $1^{\underline{a}}$ a $4^{\underline{a}}$ série e, depois, $5^{\underline{a}}$ a $8^{\underline{a}}$ série) até hoje presentes naquilo que, no Brasil, a legislação vigente nomeia ensino fundamental.

12. "Mais ainda: à medida que as manufaturas se aperfeiçoam, as suas operações dividem-se cada vez mais ou tendem, sem cessar, a encarregar cada indivíduo dum trabalho puramente mecânico e reduzido a um pequeno número de movimentos simples, trabalho que ele executa melhor e mais prontamente, mas apenas em conseqüência do hábito e no qual o seu espírito deixa quase inteiramente de atuar. Assim, o aperfeiçoamento da arte converter-se-ia, para uma parte da espécie humana, numa causa de estupidez; faria nascer em cada nação uma classe de homens incapazes de se elevarem acima dos interesses mais grosseiros e produziria uma desigualdade humilhante e um germe de perturbações perigosas, se uma instrução mais extensa não oferecesse aos indivíduos desta mesma classe um recurso contra 0 efeito infalível da monotonia das suas ocupações diárias" (Condorcet, 1943, p. 20).

13. "O que nós sabemos pelo exame de sua obra e de sua vida pode ser resumido em uma proposição muito simples que dá a linha mestra de seu retrato científico. Condorcet não é um sábio; é um enciclopedista. Tomando a palavra por seu sentido etimológico, definirse-á o gênero do espírito pelo gosto universal das ciências, a ambição de abraçar e sintetizar o conjunto do saber humano" (Granger, 1956, p. 12).

14. "É preciso saber distinguir nas leis as conseqüências destes direitos e os meios mais ou menos felizmente combinados para assegurar a sua garantia; amar a uns porque a natureza os ditou e aos outros porque foram ditados pela sua sabedoria. É preciso saber distinguir esta consagração da razão devida às leis que ela aprova, desse outro acatamento, desse apoio exterior que 0 cidadão lhe deve também, ainda quando a sua inteligência lhe mostre os seus perigos e as suas imperfeições. É preciso que, amando as leis, se saiba julga-las" (Condorcet, 1943, p. 36-37).

15. Para o Relatório, era clara a idéia corretiva quando se pretendia promover justiça ao espraiar 0 máximo possível de instrução pública. Era dever de democratização social: "Este terceiro grau de instrução dará aos que o aproveitem uma superioridade real que a distribuição das funções sociais torna inevitável; mas é mais um motivo para desejar que esta superioridade seja a da razão e da verdadeira cultura; para procurar formar homens instruídos 
e não homens espertos; para não esquecer, enfim, que os inconvenientes desta superioridade se atenuam à medida que ela é partilhada por maior número de indivíduos; que, quanto mais ilustrados são os que a gozam, menos perigosa ela é; e que, então, é o verdadeiro, o único remédio contra esta superioridade de esperteza que, em vez de dar apoio e guia à ignorância, só é fecunda em meios de a seduzir" (Condorcet, 1943, p. 37-38).

16. "É preciso não confundir a Sociedade Nacional, tal como a temos concebido, com as sociedades sábias que substitui: - a igualdade real que é a sua base; a independência absoluta com relação ao poder executivo; a inteira liberdade de opiniões que partilha com todos os cidadãos; as funções que lhe são atribuídas, relativamente à instrução pública; uma distribuição de trabalho que a força a não se ocupar senão de assuntos úteis e um número igual dos seus membros, repartidos pelos departamentos - todas estas diferenças asseguram que não merecerá as críticas, com freqüência exageradas, mas algumas vezes justas, de que as academias têm sido alvo. (...) Então, cada homem se ocupava de obter e de alargar prerrogativas; hoje, todos sabem que só os cidadãos têm direitos e que o título de funcionários públicos só dá deveres a cumprir" (Condorcet, 1943, p. 80-81).

\section{Referências bibliográficas}

BACZKO, B. L umières de l'utopie. Paris: Payot, 1978.

BAD INTER, E. (Org.). Palavras de homem (1790-1793): Condorcet, Prudhomme, Guyomar. Rio de Janeiro: Nova Fronteira, 1991.

BASTID E, P.A. L a doctrine de l'education universelle dans la philosophie d'A uguste Comte. Paris: PUf, 1957. v.2

BOTO, C. A escola do homem novo: entre o Iluminismo e a Revolução Francesa. São Paulo: UNESP, 1996.

BUISSO N, F. C ondorcet. Paris: F. Alcan, 1929.

CAHEN, L. C ondorcet et la Revolution Française. Genève: Slatkine, 1970.

CATRO GA, F. Caminhos do fim da história. Coimbra: Q uarteto, 2003.

CO ND O RCET. Instrução pública e organização do ensino. Porto: Educação Nacional, 1943.

COND ORCET. Rapport et projet de décret sur l'organisation générale de l'instruction publique; présentés à l'Assemblée Nationale, au nom du Comité d'Instruction Publique, par Condorcet, D éputé du Département de Paris. Paris: Imprimerie Nationale, 1793. E nfanœ, Paris, v. 42, n. 4, 1989.

GRANGER, G.G. L a mathématique sociale du Marquis de Condorcet. Paris: PUF, 1956. 
HO BSBAWM, E.J. A carreira aberta ao talento. In: HobsBawm, E.J. A era das revolucooes: Europa 1789-1848. 3. ed. Rio de Janeiro: Paz \& Terra, 1981.

KANT, I. Resposta à pergunta: que é o Iluminismo? (1784). In: KANT, I. A paz perpétua e outros opúsculos. Lisboa: Edições 70, 1989.

NASCIMENTO, M.M. 0 pinião pública e revolução. São Paulo: Nova Stella/ ED USP, 1989.

ROMANO, R. Moral e ciência: a monstruosidade no século XVIII. São Paulo: SENAC, 2003.

ROUSSEAU, J.-J. E mílio ou da educação. 3. ed. São Paulo; Rio de Janeiro: D ifel, 1979.

SNYDERS, G. L a pédagogie en France aux X V IIe et X V IIe. siècles. Paris: PUF, 1965.

VIAL, F. C ondorcet et l'éducation démocratique. G enève: Slatkine, 1970. VO LTAIRE. Tratado sobre a tolerância. São Paulo: Martins Fontes, 2000. VOVELLE, M. L a mentalité révolutionnaire. Paris: Messidor/ Editions Sociales, 1985. 